\title{
Grand Design Politik Hukum Pidana dan Sistem Hukum Pidana Indonesia Berdasarkan Pancasila dan Undang-Undang Dasar Negara Republik Indonesia 1945
}

\author{
Rocky Marbun ${ }^{33}$
}

\begin{abstract}
Abstrak
Politik hukum nasional telah menetapkan Indonesia sebagai negara yang berlandaskan hukum (rechtsstaat), sebagaimana diatur dalam Pasal 1 ayat (3) UUD 1945. Konsep Negara hukum tersebut mengacu kepada jiwa bangsa (volkgeist) yang termuat dalam Pancasila dan Proklamasi Kemerdekaan sebagai sumber dari segala sumber hukum dan penyangga konstitusionalisme. Sistem hukum pidana sebagai bentuk perwujudan politik hukum pidana sudah seharusnya dibentuk dengan penjiwaan UUD 1945 sebagai landasan yuridis. Konsekuensinya, sistem hukum pidana harus dijabarkan secara konkret pada setiap peraturan perundang-undangan. Namun demikian, penjiwaan Pancasila dan Proklamasi Kemerdekaan dalam sistem hukum pidana hingga saat ini belum terwujud dengan baik, misalnya adanya adopsi unsur-unsur asing. Untuk mewujudkan hal tersebut, maka pembentukan politik hukum pidana dan rancangan sistem hukum pidana nasional hendaknya membatasi keberlakuan unsur asing berdasarkan konsep harmonisasi dan sinkronisasi dengan volkgeist Indonesia yang termuat dalam Pancasila dan Proklamasi Kemerdekaan.
\end{abstract}

Kata Kunci: politik hukum pidana, sistem hukum pidana, Pancasila, Proklamasi, jiwa bangsa (volkgeist).

\section{Grand Design of the Legal Policy of Criminal Law and Indonesian Criminal Legal System Based on Pancasila and the 1945 Constitution of the Republic of Indonesia}

\begin{abstract}
The national legal policy has determined that Indonesia is a state based on Rule of Law, as provided in Article 1 paragraph (3) of the 1945 Indonesian Constitution. The concept of Legal State should also refer to the national spirit (volkgeist), as reflected in Pancasila and the Independence Proclamation as the primary source of Law and pillars of constitutionalism. Criminal law system as an enactment of legal policy of criminal law should be formulated based on the 1945 Indonesian Constitution as its juridical basis. Consequently, the criminal legal system must be translated concretely into any legislation considered part of criminal law. However, the formation of Pancasila and the Independence Proclamation has not been
\end{abstract}

33 Dosen Fakultas Hukum Universitas Bung Karno, Jl. Kimia No. 20, Menteng, Jakarta Pusat, rocky.marbun08@gmail.com, S.H. (Universitas Jayabaya), M.H. (Universitas Jayabaya). 
Rocky Marbun: Grand Design Politik Hukum Pidana dan Sistem Hukum Pidana Indonesia Berdasarkan Pancasila dan Undang-Undang Dasar Negara Republik Indonesia 1945

actualized properly, for instance: the adoption of foreign elements. Therefore, the national formation and design of the politics of criminal law and criminal legal system should limit those elements based on the concept of harmonization and synchronization with the volkgeist reflected in Pancasila and the Independence Proclamation.

Keywords: political criminal law, criminal legal system, Pancasila, Proclamation, national spirit (volkgeist)

\section{A. Pendahuluan}

Sejak era tahun tujuh puluhan, masyarakat hukum Indonesia sangat mengenal ungkapan "hukum sebagai sarana pembangunan atau sebagai sarana pembaruan masyarakat", suatu ungkapan yang memperoleh inspirasi dari Roscoe Pound "law as social engineering". " Istilah tersebut di Indonesia dipopulerkan oleh Mochtar Kusumaatmadja. Mochtar Kusumaatmadja adalah seorang penggagas pendayagunaan hukum untuk kepentingan pembangunan nasional, baik dalam praktik pembangunan dan pembinaan hukum nasional, maupun dalam pemberian arahan kurikuler pada pendidikan tinggi hukum dalam rangka penyiapan tenagatenaga ahli yang profesional. ${ }^{2}$

Paradigma keterkaitan pembangunan nasional yang menyangkut seluruh aspek kehidupan dengan antisipasi dimensi hukum merupakan suatu keniscayaan. Pembangunan menghendaki transformasi masyarakat dari suatu kondisi tertentu menjadi kondisi yang lebih baik. Manusia sebagai inti dari aktivitas pembangunan menentukan betapa 'keran' transformasi merupakan upaya operasionalisasi transformasi itu dengan sengaja. Konsep transformasi maupun operasionalisasinya bermula dari konsep normatif yang akan menuntun, mengatur, dan menertibkan perwujudannya. ${ }^{3}$ Pembentukan suatu sistem hukum nasional dan politik hukum seharusnya menjadi suatu kajian yang penting dan dengan demikian kerangka pembangunan nasional bergerak dalam koridor sistem hukum dan politik hukum yang dipahami oleh seluruh lapisan masyarakat. Penulis berangkat dari asumsi bahwa hukum bukan hanya untuk masyarakat, namun hukum juga mengikat kepada seluruh badan-badan (institusi) negara. Meskipun Cicero pernah mengatakan bahwa hukum muncul dari masyarakat, namun yang perlu dipahami adalah aparat penegak hukum juga merupakan bagian dari masyarakat itu sendiri.

1 Bagir Manan, "Peranan Hukum Dalam Mewujudkan Cita-Cita Keadilan Sosial Menurut UUD 1945”, Varia Peradilan, Tahun XXIX No. 340, Maret 2014, hlm. 7.

2 Soetandyo Wignjosoebroto, "Mochtar Kusumaatmadja: Manusia Yang Pernah Saya Kenal dan Pemikirannya (Sebuah Pengantar Ringkas)", dalam buku Mochtar Kusumaatmadja dan Teori Hukum Pembangunan: Eksistensi dan Implikasi yang disusun oleh Shidarta (et.al) Jakarta: Epistema Institute \& HuMA, 2012, hlm. Viii.

3 Abdul Gani Abdullah, Pengantar Kompilasi Hukum Islam dalam Tata Hukum Indonesia, Jakarta: Gema Insani Press, 1994, hlm. 12. 
Rocky Marbun: Grand Design Politik Hukum Pidana dan Sistem Hukum Pidana Indonesia Berdasarkan Pancasila dan Undang-Undang Dasar Negara Republik Indonesia 1945

Setiap sistem hukum setidaknya mengandung unsur-unsur berikut: (1) undangundang atau peraturan-peraturan hukum yang ditetapkan oleh lembaga legislatif; (2) keputusan-keputusan lembaga peradilan, tradisi dan prinsip-prinsip yang diakui oleh lembaga peradilan dengan efek yang mengikat secara legal; serta (3) berbagai jenis lembaga hukum yang menentukan dan menjalankan prinsip-prinsip dan keputusankeputusan hukum. Oleh karena itu, setiap undang-undang atau keputusan hukum harus ditempatkan dalam bingkai sistem hukum tersebut. ${ }^{4} \mathrm{Hal}$ tersebut sebagaimana diamanatkan dalam Pasal 1 ayat (3) Bab I, Amandemen Ketiga Undang-Undang Dasar 1945 (UUD 1945) yang menegaskan kembali bahwa "Negara Indonesia adalah Negara Hukum". Hal ini berarti bahwa Negara Kesatuan Republik Indonesia adalah negara yang berdasar atas hukum (rechtsstaat), tidak berdasar atas kekuasaan (machtstaat), dan pemerintahannya berdasarkan pada sistem konstitusi (hukum dasar), bukan absolutisme (kekuasaan yang tidak terbatas). Sebagai konsekuensi dari Pasal 1 ayat (3) Amandemen ketiga UUD 1945, terdapat tiga prinsip dasar wajib dijunjung oleh setiap warga negara yaitu: supremasi hukum; kesetaraan di hadapan hukum; dan penegakan hukum dengan cara-cara yang tidak bertentangan dengan hukum. Dengan demikian, pembentukan sistem hukum Indonesia yang ajeg menjadi suatu keharusan untuk dapat mengakomodasi kepentingan-kepentingan masyarakat pada umumnya, dan dibarengi pembatasan kekuasaan yang bersifat absolut dari institusi penegak hukum yang merupakan perpanjangan tangan atau wakil negara.

Menurut Solly Lubis, realitas kehidupan kenegaraan selama tiga dasawarsa yang lalu membuktikan terjadinya inkonsistensi dan deviasi dari konsep dasar sistem manajemen yang seharusnya, yakni UUD 1945. Sistem pemerintahan itu bergeser dari pola demokrasi kepada oligarki, berlarut-larut, sehingga akhirnya terjadi diskrepansi atau kesenjangan-kesenjangan, baik di bidang sosial politik, maupun sosial ekonomi, sosial budaya, pertahanan kemananan dan ketertiban masyarakat (Hankamtibmas). Pada prinsipnya, tuntutan reformasi sistem manajemen kehidupan bangsa secara menyeluruh itulah yang memerlukan adanya reformasi kebijakan politik dan reformasi sistem hukum, supaya manajemen nasional dapat dikembalikan kepada sistem dengan konsep dasar konstitusional. ${ }^{5}$

Munculnya fenomena benturan antara bidang hukum dengan bidang-bidang lainnya telah lama menjadi sorotan para ahli hukum di Indonesia sehingga permasalahan tersebut telah seringkali diangkat menjadi suatu topik dalam berbagai bentuk seminar, diskusi maupun lokakarya. Khususnya pada Seminar Pembangunan Hukum Nasional VIII yang diselenggarakan oleh Badan Pembinaan Hukum Nasional

4 Yong Ohoitimur, "Tujuh Teori Etika Tentang Tujuan Hukum”, Jurnal Universitas De La Salle, Vol. 1, No. 2, Oktober 2011, hlm. 1.

5 Solly Lubis, "Pembangunan Hukum Nasional", makalah disampaikan dalam Seminar Pembangunan Hukum Nasional VII Penegakan Hukum dalam Era Pembangunan Berkelanjutan, Denpasar, 14-18 Juli 2003, hlm. 1. 
Rocky Marbun: Grand Design Politik Hukum Pidana dan Sistem Hukum Pidana Indonesia Berdasarkan Pancasila dan Undang-Undang Dasar Negara Republik Indonesia 1945

(BPHN) telah secara tegas mengisyaratkan bahwa perlunya suatu grand design reformasi hukum yang sinergistik dan sistemik, yang berkorelasi dengan bidang ekonomi, politik, sosial, budaya dan agama. ${ }^{6}$ Amanah dari Seminar Pembangunan Hukum Nasional VIII tersebut sejalan dengan pendapat Sudikno Mertokusumo, bahwa hukum bukanlah tujuan, namun hukum merupakan sarana atau alat untuk mencapai tujuan yang sifatnya non-yuridis dan berkembang berdasarkan rangsangan dari luar hukum, sehingga hukum itu sendiri menjadi bersifat dinamis. ${ }^{7}$ Oleh karena itu, bergeraknya hukum sebagai sarana memerlukan pengaturan-pengaturan yang harmonis dan sinkron antara satu dengan yang lain sehingga pembentukan grand design sistem hukum memiliki fungsi sebagai wujud dari pembentukan sistem hukum dalam mencapai tujuan-tujuan hukum yang telah disepakati secara bersama.

Namun, dalam membentuk suatu sistem hukum, otoritas yang berwenang hendaknya wajib memperhatikan input hukum yang masuk ke dalam ekstraksi norma-norma hukum ke dalam regulasi yang dibentuk. Hampir sebagian besar dari kita jarang sekali memperhatikan input hukum tersebut. ${ }^{8}$ Menurut Lawrence $\mathrm{M}$. Friedmann, input hukum merupakan gelombang kejut berupa tuntutan yang bersumber dari masyarakat yang pada akhirnya menggerakan proses hukum. ${ }^{9}$ Friedmann melanjutkan bahwa mayoritas dari para ahli hukum terkonsentrasi kepada output hukum, sehingga pemahaman pembentukan suatu produk perundangundangan tidaklah komprehensif.

Permasalahan sinkronisasi bukan hanya terbatas pada ketidaksesuaian antar peraturan perundang-undangan semata, namun terkait dengan keseluruhan sistem hukum yang berlaku di Indonesia. Berbicara mengenai legal policy dalam kaitannya dengan kerangka pembaruan hukum, maka perlu diteliti keseluruhan sistem hukum yang terkait. ${ }^{10}$ Sistem hukum nasional sebagai suatu himpunan bagian hukum atau subsistem hukum yang saling berkaitan yang membentuk satu keseluruhan yang rumit atau kompleks tetapi merupakan satu kesatuan."

Menurut Achmad Ali sebagaimana mengutip pendapat Friedmann, sistem hukum terdiri atas struktur hukum (legal structure), substansi/materi hukum (legal substance), dan budaya hukum (legal culture). ${ }^{12}$ Ketika berbicara pembaharuan

6 Laporan Hasil Seminar Pembangunan Hukum Nasional VIII yang diselenggarakan oleh Badan Pembinaan Hukum Nasional (BPHN) Departemen Kehakiman dan Hak Asasi Manusia RI, Kuta-Bali, 14-18 Juli 2003, hlm. 5.

7 Sudikno Mertokusumo, Mengenal Hukum. Suatu Pengantar, Yogyakarta: Liberty, 2002, hlm. 40.

8 Lawrence M. Friedmann, The Legal System: A Social Science Perspective, [Pent. M. Khozim], Bandung: Nusamedia, 2011, hlm. 3 .

9 Ibid., hlm. 13.

10 Varia Peradilan No. 122 Tahun 1999, hlm. 146.

11 Kusnu Goesniadhie, Harmonisasi Hukum Dalam Perspektif Perundang-Undangan (Lex Spesialis Suatu Masalah), Surabaya: JP Books, 2006, hlm. 72.

12 Achmad Ali, Keterpurukan Hukum di Indonesia Penyebab dan Solusinya, Bogor: Ghalia Indonesia, 2005, hlm. 1. 
Rocky Marbun: Grand Design Politik Hukum Pidana dan Sistem Hukum Pidana Indonesia Berdasarkan Pancasila dan Undang-Undang Dasar Negara Republik Indonesia 1945

sistem peradilan pidana dalam kajian legal policy, tidak hanya kebijakan undangundang, namun juga kebijakan yang berkaitan dengan struktur dan budaya hukum yang berkembang baik secara struktural maupun bukan struktural di masyarakat. Sebenarnya pembaharuan hukum pidana tidak identik dengan pembaharuan KUHP. Pembaharuan hukum pidana lebih bersifat komprehensif dari pada sekedar mengganti KUHP. Pembaharuan hukum pidana meliputi pembaharuan dalam bidang struktur, kultur, dan materi hukum, sedangkan pembaharuan KUHP hanya berarti pembaharuan materi hukum pidana. ${ }^{13}$

Barda Nawawi Arief menyebutkan bahwa tidak ada artinya hukum pidana (KUHP) diganti/diperbaharui, apabila tidak dipersiapkan atau disertai dengan perubahan ilmu hukum pidananya. Criminal law reform atau legal substance reform harus disertai pula dengan pembaharuan ilmu pengetahuan tentang hukum pidananya (legal/criminal science reform). Hal tersebut harus disertai pula dengan pembaharuan budaya hukum masyarakat (legal culture reform) dan pembaharuan struktur atau perangkat hukumnya (legal structure reform), ${ }^{14}$ Sudarto juga berpendapat bahwa pembaharuan hukum pidana yang menyeluruh harus meliputi pembaharuan hukum pidana materiil, hukum pidana formiil, dan hukum pelaksanaan pidana. ${ }^{15}$

Berdasarkan uraian-uraian tersebut di atas, maka pembahasan terhadap wacana pembaharuan hukum (legal reform) khususnya pada hukum pidana, tidak mungkin dipisahkan antara hukum pidana materiil dengan hukum pidana formiil. Dengan demikian, baik KUHP maupun KUHAP merupakan satu kesatuan sistem hukum pidana yang saling terkait. Oleh karena itu, penentuan sistem hukum pidana sangat tergantung pada pandangan terhadap kajian politik hukum pidana yang dimiliki oleh kekuasaan legislatif di Indonesia.

Adapun kaitan antara politik hukum dengan pembentukan sistem hukum telah dijelaskan oleh Utrecht yang mengatakan bahwa sering kali pelajaran hukum umum sebagai ilmu hukum positif membuat penilaian (waarde-oordelen) tentang kaidahkaidah hukum dan sistem hukum yang telah diselidikinya dan selanjutnya menentukan hukum yang seharusnya berlaku (ius constituendum). Perihal menentukan ius constituendum ini pada pokoknya merupakan suatu perbuatan politik hukum. ${ }^{16}$ Selanjutnya menurut Utrecht, dikarenakan hukum juga menjadi

13 Ahmad Bahiej, "Pembaharuan Hukum Pidana Indonesia: Telaah atas Rancangan Kitab Undang-Undang Hukum Pidana Indonesia" kajian rutin Pusat Studi dan Konsultasi Hukum (PSKH) Fakultas Syari'ah IAIN Sunan Kalijaga Yogyakarta, 29 Desember 2003.

14 Barda Nawawi Arief, Beberapa Aspek Kebijakan Penegakan dan Pengembangan Hukum Pidana, Bandung: Citra Aditya Bakti, 1998, hIm. 133.

15 Soedarto, Pembaharuan Hukum Pidana di Indonesia, Jakarta: Bina Cipta, 1986, hlm. 27.

16 Utrecht dan Muh. Saleh Djindang, Pengantar dalam Hukum Indonesia, Jakarta: Ikhtiar, 1961, hlm. 124. 
Rocky Marbun: Grand Design Politik Hukum Pidana dan Sistem Hukum Pidana Indonesia Berdasarkan Pancasila dan Undang-Undang Dasar Negara Republik Indonesia 1945

objek politik yaitu politik hukum, maka politik hukum berusaha membuat kaidahkaidah yang akan menentukan bagaimana seharusnya manusia bertindak. Politik hukum tambah Utrecht, menyelidiki perubahan-perubahan apa yang harus diadakan dalam hukum yang sekarang berlaku supaya sesuai dengan "sociale werkelijkheid". ${ }^{17}$

Tidak berbeda jauh dengan pendapat Utrecht, dimana Teuku Mohammad Radhie mengatakan bahwa politik hukum merupakan pernyataan kehendak penguasa negara mengenai hukum yang berlaku di wilayahnya dan mengenai arah kemana hukum hendak dikembangkan. ${ }^{18}$ Terkait dengan pandangan Teuku Mohamad Radhie tersebut, Moh. Mahfud M.D. mengatakan bahwa definisi yang dikemukakan Teuku Mohammad Radhie mencakup ius constitutum atau hukum yang berlaku di wilayah negara pada saat ini dan ius constituendum atau hukum yang akan atau seharusnya diberlakukan di masa mendatang. ${ }^{19}$ Perwujudan dari pandangan politik hukum yang kemudian membentuk suatu sistem hukum tertentu yang pada akhirnya oleh lembaga yang memiliki otoritas dituangkan ke dalam peraturan perundangundangan. Pada umumnya, semua peraturan mengekspresikan adanya keputusan kolektif bahwa masyarakat atau unsur yang berkuasa menghendaki agar perilaku mengarah pada tujuan tertentu. ${ }^{20}$

Berdasarkan pendapat-pendapat tersebut, maka diketahui bahwa politik hukum dan sistem hukum memiliki keterkaitan yang sangat erat. Wawasan mengenai pandangan terhadap politik hukum akan menentukan sistem hukum yang akan digunakan pada sebuah negara. Namun demikian layaknya istilah hukum, istilah politik hukum oleh para ahli hukum banyak memiliki ketidakseragaman dalam menjabarkan pengertian-pengertiannya. L.J. Van Apeldorn pun berpendapat bahwa hal tersebut adalah suatu kewajaran dikarenakan perbedaan sudut pandang dalam menginterpretasikan suatu istilah.

Sebagai akibat dari pengaruh hubungan-hubungan hukum yang telah terjadi secara meluas dan bahkan melewati batas-batas negara atau lebih dikenal dengan istilah globalisasi, pengaruh filsafat hukum dalam membentuk politik hukum dan sistem hukum suatu negara dapat pula dikatakan sebagai salah satu unsur yang memengaruhi pola pikir dalam pembentukan hukum. C.F.G. Sunaryati Hartono berpendapat bahwa terdapat filsafah-filsafah hukum yang memengaruhi pembangunan hukum nasional baik masa lalu maupun masa saat ini. ${ }^{21}$ Apa yang terjadi di Indonesia cukup unik jika dicermati secara mendalam. Pembentukan Konstitusi Republik Indonesia sangat dipengaruhi atau sangat kental oleh nuansa

17 Ibid., hlm. 125.

18 S.F. Marbun (et.al), Hukum Administrasi Negara, Yogyakarta: UII Press, 2001, hlm. 162.

19 Moh. Mahfud M.D., Membangun Politik Hukum, Menegakkan Konstitusi, Jakarta: LP3ES, 2006, hlm. 13.

20 Lawrence M. Friedman, The Legal System: A Social Science Perspective, Op.cit., hlm. 50.

21 CFG. Sunaryati Hartono, Politik Hukum Menuju Satu Sistem Hukum Nasional, Bandung: Alumni, 1991, hlm. 52. 
Rocky Marbun: Grand Design Politik Hukum Pidana dan Sistem Hukum Pidana Indonesia Berdasarkan Pancasila dan Undang-Undang Dasar Negara Republik Indonesia 1945

sociological jurisprudence sebagaimana diwakili dengan keberadaan Pasal 33 UUD 1945 , sedangkan peraturan perundang-undangan turunannya lebih banyak dipengaruhi oleh Mahzab Positivisme Hukum dan ajaran Legisme. Seiring dengan adanya transfer ilmu hukum dari Belanda ke ahli-ahli hukum di Indonesia, meski terdapat beberapa peraturan perundang-undangan yang masih mengakui adanya nuansa hukum adat sebagai bentuk pengakuan dari negara kepada masyarakat adat di Indonesia, misalnya di dalam Undang-Undang Pokok Agraria (UUPA) yang pada Penjelasan Pasal Il angka 3 ditemukan istilah recognitie, ${ }^{22}$ namun penerapannya tetap mengejawantahkan pemikiran secara positivistik. Perkembangan pemikiran hukum di Indonesia banyak dipengaruhi oleh tradisi hukum Eropa Kontinental atau civil law yang masuk melalui kolonial Belanda dan berkembang di bawah bayang-bayang paradigma positivisme yang menjadi paradigma mainstream di tanah asalnya. Paradigma ini pada dasarnya berasal dari filsafat positivisme yang dikembangkan oleh August Comte, yang kemudian dikembangkan di bidang hukum. Paradigma positivisme memandang hukum sebagai hasil positivisasi dari norma-norma yang telah dirundingkan diantara warga masyarakat sebagai sistem aturan yang bersifat otonom dan netral. ${ }^{23}$

Apabila dikaitkan dengan upaya pembangunan nasional, tercapainya kualitas kehidupan masyarakat haruslah adil dan makmur. Pencapaian kualitas kehidupan masyarakat adil dan makmur telah diupayakan oleh Pemerintah Indonesia melalui pembangunan nasional yang berkesinambungan/berkelanjutan (sustainable development), termasuk pembangunan hukum nasional yang terprogram dalam Rencana Pembangunan Jangka Panjang (RPJP) yang termuat dalam Visi dan Misi Program Legislasi Nasional Tahun 2005-2009 (Keputusan DPR-RI No.01/DPR $\mathrm{RI} / \mathrm{III} / 2004-2005)$. Selanjutnya digunakan kata Prolegnas, sebagai berikut:

"Pembangunan hukum nasional merupakan bagian dari sistem pembangunan nasional yang bertujuan mewujudkan tujuan negara untuk melindungi segenap rakyat dan bangsa, serta seluruh tumpah darah Indonesia, memajukan kesejahteraan umum, mencerdaskan kehidupan bangsa dan ikut melaksanakan ketertiban dunia yang berdasarkan kemerdekaan, perdamaian abadi, dan keadilan sosial, melalui suatu sistem hukum nasional. Program pembangunan hukum perlu menjadi prioritas utama karena perubahan terhadap Undang-Undang Dasar Negara Republik

22 Yance Arzona, Antara Teks dan Konteks, Dinamika Pengakuan Hukum Terhadap Hak Masyarakat Adat Atas Sumber Daya Alam di Indonesia, Jakarta: HuMA, 2010, hlm. 5.

23 Khudzaifah Dimyati, Dominasi Pemikiran Hukum Positivistik: Otokritik dan Otensitas dan Kemiskinan KeIndonesia-an, Konferensi Nasional ke-3 Asosiasi Filsafat Hukum Indonesia (AFHI) "Melampaui Perdebatan Positivisme Hukum dan Teori Hukum Kodrat”, 27-28 Agustus 2013, hlm. 1. 
Rocky Marbun: Grand Design Politik Hukum Pidana dan Sistem Hukum Pidana Indonesia Berdasarkan Pancasila dan Undang-Undang Dasar Negara Republik Indonesia 1945

Indonesia Tahun 1945 memiliki implikasi yang luas dan mendasar dalam sistem ketatanegaran yang perlu diikuti dengan perubahan-perubahan di bidang hukum/penataan sistem hukum".

Apabila dicermati, maka tampak jelas terdapat korelasi sistemik antara pembangunan nasional dengan pembangunan sistem hukum nasional dalam pencapaian tujuan nasional, yaitu kesejahteraan dan perlindungan masyarakat yang secara global ikut serta dalam upaya melaksanakan ketertiban dunia. Maka permasalahan yang menarik untuk dibahas saat ini adalah apakah Pancasila dan UUD 1945 dapat menjadi landasan politik hukum pidana dan sistem hukum pidana di Indonesia?

\section{B. Politik Hukum Pidana}

Secara etimologis, istilah politik hukum merupakan terjemahan bahasa Indonesia dari istilah hukum Belanda yaitu rechtspolitiek, namun hendaknya jangan dirancukan dengan istilah yang muncul yang terakhir yaitu politiekrecht karena keduanya menurut Hence van Maarseveen memiliki makna yang berbeda. ${ }^{24}$ Dalam rangka dapat memahami politik hukum pidana, sudah seharusnya kita memiliki pemahaman yang komprehensif mengenai politik hukum. Soedarto menegaskan bahwa pengertian politik hukum pidana dapat terlihat dari politik hukum pada umumnya.

Sudarto menjelaskan makna politik hukum sebagai berikut::25

1. Kebijakan dari negara melalui badan-badan yang berwenang untuk menetapkan peraturan-peraturan yang dikehendaki yang diperkirakan bisa digunakan untuk mengekspresikan apa yang terkandung dalam masyarakat untuk mencapai apa yang dicita-citakan;

2. Usaha untuk memujudkan peraturan-peraturan yang baik sesuai dengan keadaan dan situasi pada suatu waktu.

Kotan Y. Stefanus mengatakan bahwa politik hukum pada prinsipnya berarti kebijaksanaan negara mengenai hukum yang ideal (yang dicita-citakan) pada masa mendatang dan mewujudkan ketentuan hukum yang ada pada saat ini. Adanya kesamaan makna politik hukum dalam kedua dimensi pandangan tersebut terletak penekanan terhadap hukum yang dicita-citakan (ius constituendum) dan hukum yang ada pada saat ini (ius constitutum). ${ }^{26}$

Terkait dengan pengertian-pengertian tersebut, ahli hukum telah mencoba mengaitkan pengertian politik hukum dengan keahliannya. Di dalam ranah hukum

24 Imam Syaukani \& A. Ahsin Thohari, Dasar-Dasar Politik Hukum, Jakarta: Raja Grafindo Persada, 2012, hlm. 19.

25 M. Hamdan, Politik Hukum Pidana, Jakarta: Raja Grafindo Persada, 1997, hlm. 19.

26 Kotan Y. Stefanus, Perkembangan Kekuasaan Pemerintahan Negara (Dimensi Pendekatan Politik Hukum Terhadap Kekuasaan Presiden Menurut Undang-Undang Dasar 1945), Yogyakarta: Universitas Atma Jaya, 1998, hlm. 12. 
Rocky Marbun: Grand Design Politik Hukum Pidana dan Sistem Hukum Pidana Indonesia Berdasarkan Pancasila dan Undang-Undang Dasar Negara Republik Indonesia 1945

pidana, politik hukum dikenal dengan berbagai macam istilah, antara lain: penal policy; politik kriminal; dan kebijakan legislatif pidana yang kesemuanya memiliki pengertian yang hampir sama dan saling menutupi. Barda Nawawi Arief menyebutkan istilah "kebijakan" di ambil dari istilah Inggris yaitu "policy" atau istilah Belanda yaitu "politiek". Bertolak dari kedua istilah asing tersebut, maka istilah "kebijakan hukum pidana" dapat pula disebutkan dengan istilah "politik hukum pidana" yang dalam istilah asing istilah tersebut dikenal dengan policy penal, criminal law atau strafrechts politiek. ${ }^{27}$ Menurut A. Mulder, ${ }^{28}$ strafrechts politiek adalah garis kebijakan untuk menentukan:

1. Seberapa jauh ketentuan-ketentuan pidana yang berlaku perlu diubah atau diperbaharui;

2. Apa yang dapat diperbuat untuk mencegah terjadinya tindak pidana;

3. Bagaimana penyidikan, penuntutan, peradilan dan pelaksanaan pidana harus dilaksanakan.

Dengan demikian, tahap kebijakan legislatif merupakan langkah awal dan sekaligus merupakan sumber landasan dari proses konkretisasi pidana berikutnya, yaitu tahap penerapan pidana dan tahap pelaksanaan pidana. ${ }^{29}$ Soedarto menjelaskan bahwa cara kesatuan proses dalam sistem penyelenggaraan hukum pidana itu harus berupa benang sutera yang menelusuri segala fase mulai dari pemeriksaan perkara pidana sejak awal (pemeriksaan pendahuluan adalah penyelidikan) sampai akhir proses itu yaitu pelaksanaan pemidanaan, bahkan sampai sesudah selesainya perjalanan pidana oleh narapidana. ${ }^{30}$ Soedarto menjelaskan bahwa politik hukum pidana merupakan bagian dari politik kriminal, yang terbagi menjadi tiga bagian, yaitu: ${ }^{31}$

1. Dalam pengertian sempit, politik kriminal digambarkan sebagai keseluruhan asas dan metode yang menjadi dasar dari reaksi terhadap pelanggaran hukum pidana;

2. Dalam arti luas, politik kriminal merupakan keseluruhan fungsi aparatur penegak hukum, termasuk di dalamnya cara kerja di pengadilan dan polisi;

3. Dalam arti paling luas, politik kriminal itu merupakan keseluruhan kebijakan, yang dilakukan melalui peraturan perundang-undangan dan badan resmi, yang bertujuan untuk menegakan norma-norma sentral dari masyarakat.

Menurut Muladi, politik hukum pidana (criminal law politics) pada dasarnya merupakan aktivitas yang menyangkut proses menentukan tujuan dan cara

27 Ibid, hlm. 27

$28 \mathrm{lbid}, \mathrm{hlm} .28$.

29 Barda Nawawi Arief, Kebijakan Legislatif dalam Penanggulangan Kejahatan dengan Pidana Penjara, Semarang: Badan Penerbit UNDIP, 1994, hlm. 59.

30 Soedarto, Hukum Acara Pidana dan Perkembangan Masyarakat, Bandung: Sinar Baru, 1994, hlm. 4.

31 Soedarto, Pembaharuan Hukum Pidana di Indonesia, Op.cit., hIm. 152. 
Rocky Marbun: Grand Design Politik Hukum Pidana dan Sistem Hukum Pidana Indonesia Berdasarkan Pancasila dan Undang-Undang Dasar Negara Republik Indonesia 1945

melaksanakan tujuan tersebut. Dengan demikian, proses yang terkait merupakan proses pengambilan keputusan (decision making process) atau pemilihan melalui seleksi di antara berbagai alternatif yang ada mengenai apa yang menjadi tujuan dari sistem hukum pidana mendatang. Dalam rangka pengambil keputusan dan pilihan tersebut, disusun berbagai kebijakan (policies) yang berorientasi pada permasalahan pokok dalam hukum pidana (perbuatan yang bersifat melawan hukum, kesalahan/pertanggungjawaban pidana dan berbagai alternatif sanksi yang baik yang merupakan pidana (straf) maupun tindakan (maatregel). ${ }^{32}$

Usaha penanggulangan kejahatan melalui pembuatan undang-undang (hukum pidana) juga merupakan bagian integral dari usaha perlindungan masyarakat (social defence), oleh karenanya kebijakan atau politik hukum pidana juga merupakan bagian integral dari kebijakan atau politik sosial (social policy). ${ }^{33}$ Kebijakan sosial (social policy) dapat diartikan sebagai segala usaha yang rasional untuk mencapai kesejahteraan masyarakat sekaligus mencakup perlindungan masyarakat. Secara singkat, dapat dikatakan bahwa tujuan akhir (tujuan utama) dari politik kriminal ialah perlindungan masyarakat untuk mencapai kesejahteraan masyarakat. Hal tersebut menunjukkan arah dari kebijakan politik hukum nasional yang dilandaskan pada keinginan untuk melakukan pembenahan sistem dan politik hukum yang berdasar pada tiga prinsip dasar yang wajib dijunjung oleh setiap warga negara yaitu:

1. Supremasi hukum;

2. Kesetaraan di hadapan hukum; dan

3. Penegakan hukum dengan cara-cara yang tidak bertentangan dengan hukum.

Ketiga prinsip dasar tersebut merupakan syarat mutlak dalam mewujudkan citacita negara Indonesia yang damai dan sejahtera. Apabila hukum ditegakkan dan ketertiban diwujudkan, maka diharapkan kepastian, rasa aman, tenteram, ataupun kehidupan yang rukun dapat terwujud. Dengan demikian, politik hukum nasional harus senantiasa diarahkan pada upaya mengatasi berbagai permasalahan dalam penyelenggaraan sistem dan politik hukum yang meliputi permasalahan yang berkaitan dengan substansi hukum, struktur hukum, dan budaya hukum.

\section{Sistem Hukum Pidana}

Penggunaan istilah "sistem hukum" lebih mengarah kepada serapan dari bahasa Inggris yaitu legal system. Dalam penggunaan istilah bahasa Inggris, para ahli hukum asing tidak menggunakan istilah "Iaw" dalam istilah sistem hukum, namun menggunakan istilah"legal". Apabila merunut literatur yang ada, yang muncul adalah

32 Muladi, "Politik Hukum Pidana, Dasar Kriminalisasi dan Dekriminalisasi serta Beberapa Perkembangan asas Dalam RUU KUHP", Makalah yang dipresentasikan dalam Focus Group Discussion yang diselenggarakan oleh ELSAM “Melihat Kodifikasi dalam Rancangan KUHP”, Jakarta, 28 September 2006, hlm. 1.

33 Ibid., hlm. 6. 
Rocky Marbun: Grand Design Politik Hukum Pidana dan Sistem Hukum Pidana Indonesia Berdasarkan Pancasila dan Undang-Undang Dasar Negara Republik Indonesia 1945

legal system dan bukan law system atau the system of law, sehingga penggunaan istilah "legal system" menjadi biasa dan dapat dipersamakan dengan istilah "sistem hukum". Layaknya istilah-istilah sebelumnya, istilah sistem hukum atau legal system pun memiliki beragam pemaknaan dari para ahli hukum.

Menurut Friedmann, suatu sistem hukum dalam operasi aktualnya merupakan sebuah organisme kompleks dimana struktur (structure), substansi (substance), dan kultur (culture) berinteraksi untuk menjelaskan latar belakang dan efek dari setiap bagiannya diperlukan peranan dari banyak elemen sistem tersebut. ${ }^{34}$ Dengan kata lain, suatu sistem hukum diandaikan untuk menjamin distribusi tujuan dari hukum secara benar dan tepat di antara orang-orang dan kelompok. ${ }^{35}$ Achmad Ali menambahkan pendapat Friedmann dengan memasukkan unsur profesionalisme dan kepemimpinan. ${ }^{36}$ Hampir sejalan dengan pendapat Friedmann, Sudikno Mertokusumo menjelaskan bahwa hukum merupakan sistem yang berarti bahwa hukum merupakan tatanan dan suatu kesatuan yang utuh yang terdiri dari bagianbagian atau unsur-unsur yang saling terkait erat satu sama lain. Sistem hukum adalah suatu kesatuan yang terdiri dari unsur-unsur yang mempunyai interaksi satu sama lain dan bekerja sama untuk mencapai tujuan kesatuan tersebut. ${ }^{37}$ Suatu sistem hukum yang bergerak seakan melingkar dan saling terkoneksi tanpa adanya jeda-jeda yang dapat menjadikan hambatan dalam bekerjanya hukum dalam suatu sistem. Agar tercapainya dan bergeraknya suatu sistem hukum, maka C.F.G. Sunaryati Hartono berpendapat bahwa dibutuhkan suatu organisasi yang dilandaskan kepada asas-asas tertentu. ${ }^{38}$

Sebagaimana diungkapkan oleh Konnie G. Kustron, bahwa legal system adalah suatu organisasi sosial dan kontrol dari pemerintah yang menciptakan dan mengatur ketentuan-ketentuan dalam masyarakat melalui perundang-undangan. Organisasi tersebut mengatur sistem peraturan dan membuat rancangan peraturan untuk mendorong terciptanya perilaku yang baik dan mengurangi perilaku yang negatif. ${ }^{39}$ Dengan kata lain, sistem hukum adalah suatu kumpulan unsur-unsur yang ada dalam interaksi satu sama lain yang merupakan satu kesatuan yang terorganisasi dan kerja sama ke arah tujuan kesatuan..$^{40}$ Oleh karena itu, pada dasarnya sistem hukum adalah suatu struktur formal. ${ }^{41}$

34 Lawrence M. Friedmann, The Legal System. A Social Science Perspective, Op.cit, hlm. 18.

35 Ibid., hlm. 19.

36 Achmad Ali, Menguak Teori Hukum (Legal Theory) dan Teori Peradilan (Judicialprudence) Termasuk Interpretasi Undang-Undang (Legisprudence), Jakarta: Kencana, 2012, hlm. 204.

37 Sudikno Mertokusumo, Mengenal Hukum: Suatu Pengantar, Op.cit., hlm. 115.

38 CFG. Sunaryati Hartono, Politik Hukum Menuju Satu Sistem Hukum Nasional, Op.cit., hlm. 56.

39 Konnie G. Kustron, Loc. cit.

40 Sudikno Mertokusumo, Penemuan Hukum, Yogyakarta: Universitas Atma Jaya Yogyakarta, 2010, hlm. 24.

41 Mochtar Kusumaatmadja \& B. Arief Sidharta, Pengantar Ilmu Hukum: Buku I, Bandung: Alumni, 2013, hlm. 121. 
Rocky Marbun: Grand Design Politik Hukum Pidana dan Sistem Hukum Pidana Indonesia Berdasarkan Pancasila dan Undang-Undang Dasar Negara Republik Indonesia 1945

Berangkat dari pendapat R. Subekti, sistem adalah suatu susunan atau catatan teratur, suatu keseluruhan yang terdiri dari bagian-bagian yang berkaitan satu sama lain tersusun menurut suatu rencana atau pola hasil dari suatu pemikiran untuk mencapai suatu tujuan. Dalam suatu sistem yang baik, tidak boleh terjadi suatu duplikasi atau tumpang tindih (overlapping) di antara bagian-bagian itu. ${ }^{42}$

Ahmad Muliadi mencoba memberikan definisi terhadap istilah sistem hukum sebagai berikut: ${ }^{43}$

"Sistem hukum mengandung makna struktur menyeluruh atas ruang lingkup dari ilmu-ilmu hukum yang tercakup di dalamnya kaidah-kaidah hukum, keputusan-keputusan pejabat, (hukum) kebiasaan. Atau jelasnya ilmu-ilmu hukum yang menyajikan suatu rekonstruksi sistematis dari sebagian fakta yang ditelaah dalam lingkup suatu negara (Indonesia). Sistem hukum dapat dipelajari dalam hal logis dan sistematis."

Pendapat diatas memiliki kemiripan dengan pendapat yang diungkapkan oleh Meuwissen yang menjelaskan bahwa sistem hukum sebagai konstruksi (teoretis) yang di dalamnya norma/kaidah hukum dipikirkan dalam suatu hubungan logiskonsisten menjadi suatu kesatuan tertentu. ${ }^{44}$ Notonagoro menggunakan istilah yang cukup menarik dalam menguraikan makna sistem hukum. Beliau menjelaskan sebagai berikut: ${ }^{45}$

"Yang dimaksud dengan tertib hukum adalah keseluruhan daripada peraturanperaturan hukum yang memenuhi empat syarat: (1) ada kesatuan subyek yang mengadakan peraturan-peraturan hukum; (2). ada kesatuan asas kerohanian yang meliputi keseluruhan peraturan-peraturan itu; (3). ada kesatuan waktu dalam mana peraturan-peraturan hukum itu berlaku; dan (4) ada kesatuan daerah dimana peraturan-peraturan hukum itu berlaku."

Berdasarkan uraian Notonagoro tersebut, jelas sekali bahwa yang dimaksud dengan "tertib hukum" identik dengan sistem hukum yang Penulis bahas. Berdasarkan berbagai uraian yang berkaitan dengan pendefinisian sistem hukum, pendapat Friedmann sangat tepat dalam menyimpulkan berbagai makna di atas. Friedmann menjelaskan bahwa sistem hukum memiliki lebih banyak lagi kode aturan (codes of ruler), aturan (do's and don'ts), peraturan (regulations) dan perintah (orders). Hal tersebut disebabkan karena kata "hukum" seringkali mengacu bukan hanya pada aturan dan peraturan, namun dapat dibedakan antara aturan dan

42 Ahmad Muliadi, Politik Hukum, Padang: Akademia Permata, 2013, hlm. 46.

$43 \mathrm{lbid}$.

44 Titon Slamet Kurnia, Pengantar Sistem Hukum Indonesia, Bandung: Alumni, 2009, hlm. 11.

45 Hyrominus Rhiti, Filsafat Hukum. Edisi Lengkap dari Klasik Sampai Postmodernisme, Yogyakarta: Universitas Atma Jaya, 2011, hlm. 387. 
Rocky Marbun: Grand Design Politik Hukum Pidana dan Sistem Hukum Pidana Indonesia Berdasarkan Pancasila dan Undang-Undang Dasar Negara Republik Indonesia 1945

peraturan itu sendiri serta struktur, lembaga, dan proses yang mengisinya. Maka bidang yang luas tersebut lah yang disebut "sistem hukum". 46

Berdasarkan pemikiran para ahli hukum di atas, hampir bisa ditarik persamaan bahwa suatu sistem hukum itu merupakan kumpulan dari unsur atau komponen atau sub-sistem yang saling memiliki keterkaitan. Namun demikian, sistem hukum merupakan dependent variable (variabel yang terpengaruhi), sedangkan politik hukum merupakan independent variable (variable yang mempengaruhi). Perbedaannya terletak kepada jenis-jenis dari unsur atau komponen atau sub-sistem yang saling terkait tersebut. Oleh karena itu, dalam memahami suatu sistem hukum atau legal system, terdapat dua hal yang wajib dipahami dengan baik, yaitu:

1. Model-model sistem hukum atau legal systems; dan

2. Unsur-unsur atau komponen atau sub-sistem yang menjadi satu kesatuan.

Sebagaimana diketahui, bahwa sistem hukum yang hidup di dunia ini sangat banyak, walaupun para ahli hukum sebahagian besar hanya mengelompokkan kepada dua kelompok besar sistem hukum, yaitu common law dan civil law. Maka penentuan sistem hukum yang akan digunakan inilah yang akan menentukan arah sistem hukum pidana di Indonesia, walaupun jika ditilik dari sisi sejarah hukum, Bangsa Indonesia pernah menerapkan pada masa sebelum masa penjajahan yaitu suatu sistem hukum yang didasarkan kepada the living law.

\section{Pancasila dan Undang-Undang Dasar Negara Republik Indonesia 1945 sebagai Landasan Politik Hukum Pidana dan Sistem Hukum Pidana di Indonesia}

Patut kita cermati bersama bahwa perkembangan dalam masyarakat akibat globalisasi telah mempengaruhi dalam tatanan hukum nasional bangsa-bangsa. Globalisasi telah menimbulkan dampak di berbagai bidang seperti munculnya kecenderungan negara tanpa batas (state without border). Pada akhirnya norma hukum yang ada harus mampu menyesuaikan diri dengan perubahan-perubahan yang terjadi, namun bukan berarti harus menanggalkan nilai-nilai yang dianut, seperti pandangan hidup, ideologi dan dasar negara Pancasila yang telah menjadi sumber dari segala sumber hukum. ${ }^{47}$

Menurut Barda Nawawi Arief, pembaharuan hukum pidana pada hakikatnya merupakan suatu upaya melakukan peninjauan dan pembentukan kembali (reorientasi dan reformasi) hukum pidana yang sesuai dengan nilai-nilai sentral sosiopolitik, sosiofilosofis, dan nilai-nilai sosiokultural masyarakat Indonesia, ${ }^{48}$

Lawrence M. Friedman, American Law. An Introduction, terjemahan Wishnu Basuki, Jakarta: Tata Nusa, 2001, hlm. 4.

47 Endang Sutrisno, Bunga Rampai Hukum dan Globalisasi, Bandung: Genta Press, 2011, hlm. 90-91.

48 Barda Nawawi Arief, Tujuan dan Pedoman Pemidanaan, Semarang: Badan Penerbit Magister, 2011 , hlm. 43. 
Rocky Marbun: Grand Design Politik Hukum Pidana dan Sistem Hukum Pidana Indonesia Berdasarkan Pancasila dan Undang-Undang Dasar Negara Republik Indonesia 1945

sehingga ketika kita mempermasalahkan tersingkirnya Pancasila sebagai sumber hukum yang menginspirasi sistem hukum Indonesia, khususnya hukum pidana. Permasalahan lain pun muncul, yaitu dimanakah letak hukum pidana adat dan hukum Islam yang notabene kedua sistem hukum tersebut pernah berlaku dan masih berlaku pada sebagian masyarakat Indonesia. Hal tersebut turut dipertanyakan oleh Valerine J.L. Kriekhoff, yakni apakah hukum adat masih diakui eksistensinya? ${ }^{49}$ Proses modernisasi telah melenyapkan dasar kemasyarakatan dari hukum kebiasaan tradisional hukum adat (hampir) sebagian besar tanah air. ${ }^{50}$

Sejak dasawarsa 1950-an, proses internasionalisasi semakin menembus batasbatas wilayah negara nasional yang dipercepat dengan semakin banyaknya kegiatan kerjasama ekonomi, bantuan ekonomi internasional serta penanaman modal asing. Keharusan untuk semakin memperbesar produksi dan adanya penemuan-penemuan baru di bidang teknologi, komunikasi, dan telekomunikasi mengakibatkan semakin banyak produk tidak lagi dihasilkan di satu negara, tetapi di berbagai negara dimana biaya produksinya paling rendah. ${ }^{51}$ Pada akhirnya, perkembangan hukum nasional menjadi tergantung kepada beberapa faktor, antara lain: ${ }^{52}$

1. Ukuran keperluan yang mendesak (urgent need), kadang-kadang tidak dapat dikatakan kita dihadapkan pada pilihan dimana kita sering terdesak untuk segera melakukannya tanpa kesempatan memilih dalam arti yang sebenarnya;

2. Feasibility (kelayakan), bidang-bidang hukum yang mengandung terlalu banyak halangan ditangguhkan dan dipilih bidang-bidang yang tidak ada kompilasikompilasi kultural, keamanan dan sosiologis;

3. Fundamental change (perubahan yang pokok), perubahan melalui peraturan perundang-undangan diperlukan dikarenakan pertimbangan-pertimbangan politis, ekonomis dan/atau sosial. Perubahan hukum demikian sering diadakan oleh negara-negara bekas jajahan dengan pemerintah yang memiliki kesadaran politik yang tinggi.

Sebagai akibat dari munculnya faktor-faktor tersebut, maka salah satu pilihan dalam mengembangkan sistem hukum nasional adalah munculnya pilihan penggunaan model-model hukum asing. Namun demikian, Mochtar Kusumaatmadja menjelaskan bahwa terkadang ada sisi keuntungannya, tetapi hendaknya tetap memperhatikan hambatan-hambatan penggunaan model hukum asing telah diadaptasi atau diubah sesuai kondisi. ${ }^{53}$ Mochtar Kusumaatmadja menganjurkan

49 Valerine J.L. Kriekhoff, "Arah Pembaharuan Hukum Pidana Nasional-Penggunaan Hukum Adat", Makalah dipresentasikan pada Seminar Pengkajian Hukum Nasional Tahun 2013 (SPHN 2013) dengan, tema "Arah Pembangunan Hukum Pidana Nasional", Jakarta, 26-27 November 2013.

50 Mochtar Kusumaatmadja \& B. Arief Sidharta, Pengantar Ilmu Hukum: Buku I, Op.cit., hlm. 131.

51 CFG. Sunaryati Hartono, Politik Hukum Menuju Satu Sistem Hukum Nasional, Op.cit., hlm. 67.

52 Mochtar Kusumaatmadja \& B. Arief Sidharta, Pengantar Ilmu Hukum: Buku I, Op.cit., hlm. 32-34.

53 Ibid. 
Rocky Marbun: Grand Design Politik Hukum Pidana dan Sistem Hukum Pidana Indonesia Berdasarkan Pancasila dan Undang-Undang Dasar Negara Republik Indonesia 1945

bahwa konsep-konsep dan asas-asas hukum tradisional adakalanya perlu dipertahankan di bidang-bidang hukum yang erat hubungannya dengan kehidupan sosial budaya yang masih kuat dipegang oleh masyarakat tradisional. ${ }^{54}$

Jika ditilik dari TAP MPR Nomor IV/MPR/1999 tentang Garis-Garis Besar Haluan Negara Tahun 1999-2004, seharusnya pembentukan sistem hukum pidana dapat menolak paham-paham asing yang bertentangan dengan Pancasila untuk masuk ke Indonesia dengan parameter standar yaitu tidak bertentangan dengan visi misi bangsa untuk mengamalkan Pancasila secara konsisten dalam kehidupan bermasyarakat, berbangsa dan bernegara. Dengan telah dikembangkannya Pancasila menjadi 36 butir kaidah-kaidah turunan dari kelima sila, seharusnya dapat dijadikan sebagai patokan dasar dalam membangun sistem hukum pidana nasional. Oleh karena itu, penggalian nilai-nilai yang ada dalam bangsa Indonesia dalam usaha pembaharuan hukum pidana Indonesia harus dilakukan agar hukum pidana Indonesia di masa depan sesuai dengan sosiopolitik, sosiofilosofis, dan nilai-nilai sosiokultural masyarakat Indonesia. ${ }^{55}$

Demikian pula diungkapkan oleh C.F.G. Sunaryati Hartono, bahwa politik hukum Indonesia disatu pihak tidak terlepas dari realitas sosial dan tradisional yang terdapat di Indonesia sendiri. Dilain pihak, sebagai salah satu anggota masyarakat dunia, politik hukum Indonesia tidak terlepas pula dari realita dan politik hukum internasional. Dengan demikian, faktor-faktor yang akan menentukan politik hukum tidak semata-mata ditentukan oleh apa yang dicita-citakan atau tergantung pada kehendak pembentuk hukum, praktisi atau para teoretisi belaka, akan tetapi ikut ditentukan pula oleh kenyataan serta perkembangan hukum di negara lain serta perkembangan hukum Internasional. ${ }^{56}$

Pengalaman "mendamaikan" isi kandungan hukum antara hukum yang diberi sanksi negara dengan hukum rakyat (atau sebut saja kaidah-kaidah sosial yang tersosialisasi dan diyakini oleh warga masyarakat-masyarakat lokal) sebagaimana diperoleh pada zaman kolonial yang sedikit banyak boleh dibilang sukses, ternyata justru sulit dilaksanakan pada zaman kemerdekaan. Pluralitas hukum rakyat yang diakui berlaku sebagai living law berdasarkan paham partikularisme pada zaman kolonial tidaklah mudah diteruskan pada zaman kemerdekaan. Cita-cita nasional memang untuk "menyatukan" Indonesia sebagai satu kesatuan politik namun pemerintahan saat ini cenderung mengabaikan hukum rakyat yang bersifat plural dan lokal untuk diganti dengan hukum nasional yang sudah terunifikasi dan terkodifikasi. Kebijakan hukum nasional ditantang untuk merealisasi cita-cita menfungsikan

54 Mochtar Kusumaatmadja \& B. Arief Sidharta, Pengantar Ilmu Hukum:Buku I, Op.cit., hlm. 133.

55 Marcus Priyo Gunarto, Asas Keseimbangan Dalam Konsep Rancangan Undang-Undang Kitab Undang-Undang Hukum Pidana, Jurnal Mimbar Hukum, Vol. 24, Nomor 1, Februari 2012, hlm. 86.

56 M. Hamdan, Politik Hukum Pidana, Op.cit., hlm. 6. 
Rocky Marbun: Grand Design Politik Hukum Pidana dan Sistem Hukum Pidana Indonesia Berdasarkan Pancasila dan Undang-Undang Dasar Negara Republik Indonesia 1945

kaidah-kaidah sebagai kekuatan pembaharu, mendorong terjadinya perubahan dari wujud masyarakat-masyarakat lokal yang agraris ke kehidupan-kehidupan baru yang lebih urban dan industrial dalam format dan skala yang nasional (dan bahkan kini juga global), ${ }^{57}$ B. Arief Sidharta mengungkapkan bahwa dengan diproklamirkan kemerdekaan Negara Republik Indonesia melalui Proklamasi Kemerdekaan, maka sebenarnya secara implisit sudah terjadi perubahan dalam isi cita hukum sebagai asas dasar yang memedomani (basic guiding principles) dalam penyelenggaraan hukum di Indonesia. ${ }^{58}$

Maka sebagai dasar pembentukan politik hukum pidana dan sistem hukum pidana di Indonesia, hal tersebut seyogyanya didasarkan kepada Proklamasi Kemerdekaan dan Pancasila sebagai cita hukum dalam pembangunan hukum di Indonesia. Pembangunan hukum pidana di Indonesia tidak dapat disandarkan kepada Undang-Undang Dasar sebagai konstitusi suatu negara karena UUD sebagai konstitusi pada prinsipnya merupakan pengejawantahkan dari Proklamasi Kemerdekaan dan Pancasila.

Pandangan Penulis tersebut telah terkonfirmasi dengan mengacu kepada pendapat dari Sudikno Mertokusumo yang mengatakan sebagai berikut: ${ }^{59}$

"Karena euphoria maka kita ada dalam keadaan senang-senangnya (mbungahi) membuat atau mengubah, merevisi atau mengamandemen undang-undang dan mengubah undang-undang baru. Undang-Undang Dasar saja dirubah."

Oleh karena itu, pembentukan grand design ini seharusnya dikembalikan kepada jiwa bangsa Indonesia yang termuat di dalam Pancasila. Bernard Arief Sidharta menjelaskan pandangan hidup bangsa Indonesia telah dirumuskan secara padat dalam Pancasila dan dengan termuatnya Pancasila di dalam Pembukaan UUD 1945 telah menunjukan bahwa dengan Pancasila menjadi dasar kefilsafatan yang menjiwai penyusunan ketentuan-ketentuan yang tercantum dalam UUD 1945. Dengan demikian, Pancasila melandasi dan seharusnya menjiwai kehidupan kenegaraan di Indonesia, termasuk kegiatan menentukan dan melaksanakan politik hukumnya.

Hal tersebut menjadi sejalan jika setiap legislator memahami bahwa paham negara hukum dalam budaya hukum Indonesia mendudukan kepentingan orang perorangan secara seimbang dengan kepentingan umum. Artinya, menurut Khudzaifah Dimyati, negara mengakui hak dan kewajiban asasi warga negara serta melindunginya, sementara negara diberikan kekuasaan untuk melindungi hak dan

57 Soetadyo Wignjosoebroto, Hukum, Paradigma, Metode dan Masalah, Jakarta: ELSAM dan HUMA, 2002, hlm. 166-167.

58 Bernard Arief Sidharta, IImu Hukum Indonesia: Upaya Pengembangan Ilmu Hukum Sistematik Yang Responsif Terhadap Perubahan Masyarakat, Bandung: Genta Publishing, 2013, hlm. 95.

59 Sudikno Mertokusumo, Kapita Selekta Ilmu Hukum, Yogyakarta: Liberty, 2013, hlm. 83. 
Rocky Marbun: Grand Design Politik Hukum Pidana dan Sistem Hukum Pidana Indonesia Berdasarkan Pancasila dan Undang-Undang Dasar Negara Republik Indonesia 1945

kewajiban asasi rakyatnya serta membuat pengaturan-pengaturan yang memungkinkan terjaminnya kehidupan masyarakat aman, tentram, dan damai. Paham negara hukum dalam budaya hukum Indonesia tidak mendudukkan kepentingan individu di atas segala-galanya, seperti di negara-negara Barat, dan tidak pula mendudukkan kepentingan negara di atas segala-galanya dengan mengorbankan kepentingan masyarakat. Berdasarkan perspektif paham negara hukum dan falsafah hidup bangsa Indonesia, maka kepentingan individu dan kepentingan masyarakat diletakkan dalam posisi seimbang. ${ }^{60}$

\section{E. Penutup}

Di dalam konteks negara hukum, melalui UUD 1945, politik hukum nasional telah menetapkan bahwa Indonesia adalah negara berdasarkan hukum, sebagaimana diatur dalam Pasal 1 ayat (1) UUD 1945, dimana sebelumnya, dalam UUD 1945 (sebelum amandemen) ditegaskan bahwa Negara Indonesia berdasarkan hukum (rechsstaat). Dalam hal tersebut, pembentuk konstitusi hendak menjelaskan bahwa politik hukum Indonesia tidak lagi menyandarkan kepada bentuk negara hukum (rechtsstaat). Konsep negara hukum Bangsa Indonesia hendaknya mengacu kepada jiwa bangsa sebagaimana termuat di dalam Pancasila dan Proklamasi.

Namun demikian, perwujudan Pancasila dan Proklamasi sebagai dasar dari politik hukum pidana dan sistem hukum pidana merupakan suatu proses yang melalui tahapan-tahapan yang hingga saat ini belum mampu diwujudkan dengan baik. Maka hendaknya untuk menutupi loop holes tersebut, pembentukan politik hukum pidana dan perancangan sistem hukum pidana secara nasional mengadopsi unsur-unsur asing yang dibatasi keberlakuannya berdasarkan konsep harmonisasi dan sinkronisasi dengan jiwa bangsa (volkgeist) Indonesia yang termuat di dalam Pancasila dan Proklamasi. Dengan pendekatan demikian, Indonesia dapat mempertahankan identitas hukum nasional.

Bahwa dalam membentuk Politik Hukum Pidana hendaknya didasarkan kepada Pancasila sebagai landasan filosofi pembentukannya, dimana Pancasila sebagai groundnorm telah memuat norma-norma abstrak yang memberikan peluang untuk menentukan apa yang benar dan apa yang baik. Sebagai norma dasar, Pancasila secara implisit telah mendasari berbagai norma positif di Indonesia ke dalam peraturan perundang-undangan. Hal tersebut menjadi suatu kewajaran, dikarenakan secara aklamasi Pancasila telah ditetapkan sebagai sumber dari segala sumber hukum dan merupakan penyangga konstitusional. Perwujudan politik hukum pidana ke dalam sistem hukum pidana, hendaknya pembentukan sistem hukum pidana

60 Khudzaifah Dimyati, Teorisasi Hukum. Studi Tentang Perkembangan Pemikiran Hukum di Indonesia 1945-1990, Bandung: Genta Publishing, 2010, hlm. 206. 
Rocky Marbun: Grand Design Politik Hukum Pidana dan Sistem Hukum Pidana Indonesia Berdasarkan Pancasila dan Undang-Undang Dasar Negara Republik Indonesia 1945

dijiwai oleh UUD 1945 sebagai landasan yuridis yang harus dijabarkan secara konkret ke dalam setiap peraturan perundang-undangan yang bersifat hukum pidana.

\section{Daftar Pustaka}

\section{Buku}

Abdul Gani Abdullah, Pengantar Kompilasi Hukum Islam Dalam Tata Hukum Indonesia, Gema Insani Press, Jakarta, 1994.

Achmad Ali, Keterpurukan Hukum di Indonesia Penyebab dan Solusinya, Ghalia Indonesia, Bogor, 2005.

, Menguak Teori Hukum (Legal Theory) dan Teori Peradilan (Judicialprudence) Termasuk Interpretasi Undang-Undang (Legisprudence), Kencana, Jakarta, 2012.

Ahmad Muliadi, Politik Hukum, Akademia Permata, Padang, 2013.

Barda Nawawi Arief, Beberapa Aspek Kebijakan Penegakan dan Pengembangan Hukum Pidana, Citra Aditya Bakti, Bandung, 1998. , Kebijakan Legislatif Dalam Penanggulangan Kejahatan

Dengan Pidana Penjara, Badan Penerbit UNDIP, Semarang, 1994. , Tujuan dan Pedoman Pemidanaan, Badan Penerbit Magister, Semarang, 2011.

Bernard Arief Sidharta, IImu Hukum Indonesia: Upaya Pengembangan IImu Hukum Sistematik Yang Responsif Terhadap Perubahan Masyarakat, Genta Publishing, Bandung, 2013.

C.F.G. Sunaryati Hartono, Politik Hukum Menuju Satu Sistem Hukum Nasional, Alumni, Bandung, 1991.

Endang Sutrisno, Bunga Rampai Hukum dan Globalisasi, Genta Press, Bandung, 2011.

Friedmann, Lawrence M., The Legal System: A Social Science Perspective, terjemahan M. Khozim, Nusamedia, Bandung, 2011.

American Law: An Introduction, terjemahan Wishnu Basuki, Tata Nusa, Jakarta, 2001.

Hyrominus Rhiti, Filsafat Hukum: Edisi Lengkap Dari Klasik Sampai Postmodernisme, Universitas Atma Jaya, Yogyakarta, 2011.

Imam Syaukani \& A. Ahsin Thohari, Dasar-Dasar Politik Hukum, Raja Grafindo Persada, Jakarta, 2012.

Khudzaifah Dimyati, Teorisasi Hukum: Studi Tentang Perkembangan Pemikiran Hukum di Indonesia 1945-1990, Genta Publishing, Bandung, 2010.

Kusnu Goesniadhie, Harmonisasi Hukum Dalam Perspektif Perundang-Undangan (Lex Spesialis Suatu Masalah), JP Books, Surabaya, 2006. 
Rocky Marbun: Grand Design Politik Hukum Pidana dan Sistem Hukum Pidana Indonesia Berdasarkan Pancasila dan Undang-Undang Dasar Negara Republik Indonesia 1945

Kotan Y. Stefanus, Perkembangan Kekuasaan Pemerintahan Negara (Dimensi Pendekatan Politik Hukum terhadap Kekuasaan Presiden menurut UndangUndang Dasar 1945), Universitas Atma Jaya, Yogyakarta, 1998.

M. Hamdan, Politik Hukum Pidana, Raja Grafindo Persada, Jakarta, 1997.

Marbun, SF. (et.al.), Hukum Administrasi Negara, UII Press, Yogyakarta, 2001.

Mochtar Kusumaatmadja \& B. Arief Sidharta, Pengantar IImu Hukum: Buku I, Alumni, Bandung, 2013.

Moh. Mahfud M.D., Membangun Politik Hukum, Menegakkan Konstitusi, LP3ES, Jakarta, 2006.

Shidarta., et.al., Mochtar Kusumaatmadja dan Teori Hukum Pembangunan. Eksistensi dan Implikasi, Epistema Institute \& HuMA, Jakarta, 2012.

Soetadyo Wignjosoebroto, Hukum, Paradigma, Metode dan Masalah, ELSAM dan HUMA, Jakarta, 2002.

Soedarto, Hukum Acara Pidana dan Perkembangan Masyarakat, Sinar Baru, Bandung, 1994.

Sudarto, Pembaharuan Hukum Pidana di Indonesia, Bina Cipta, Jakarta, 1986.

Sudikno Mertokusumo, Mengenal Hukum: Suatu Pengantar, Liberty, Yogyakarta, 2002.

,Penemuan Hukum, Universitas Atma Jaya Yogyakarta, Yogyakarta, 2010. Kapita Selekta Ilmu Hukum, Liberty, Yogyakarta, 2013.

Titon Slamet Kurnia, Pengantar Sistem Hukum Indonesia, Alumni, Bandung, 2009.

Utrecht dan Muh. Saleh Djindang, Pengantar dalam Hukum Indonesia, Ikhtiar, Jakarta, 1961.

Yance Arzona, Antara Teks dan Konteks, Dinamika Pengakuan Hukum terhadap Hak Masyarakat Adat atas Sumber Daya Alam di Indonesia, HuMA, Jakarta, 2010.

\section{Dokumen Lain}

Ahmad Bahiej, “Pembaharuan Hukum Pidana Indonesia (Telaah atas Rancangan Kitab Undang-Undang Hukum Pidana Indonesia)", Makalah ini disampaikan pada kajian rutin Pusat Studi dan Konsultasi Hukum (PSKH) Fakultas Syari'ah IAIN Sunan Kalijaga, Yogyakarta, 29 Desember 2003.

Bagir Manan, "Peranan Hukum Dalam Mewujudkan Cita-cita Keadilan Sosial Menurut UUD 1945", Varia Peradilan, Tahun XXIX No. 340, Maret 2014.

Khudzaifah Dimyati, "Dominasi Pemikiran Hukum Positivistik: Otokritik dan Otensitas dan Kemiskinan Ke-Indonesia-an", Makalah dipresentasikan pada Konferensi Nasional ke-3 Asosiasi Filsafat Hukum Indonesia (AFHI), dengan tema: Melampaui Perdebatan Positivisme Hukum dan Teori Hukum Kodrat, yang diselenggarakan oleh AFHI dan Epistema Institute bekerjasama dengan Fakultas Hukum Universitas Airlangga, 27-28 Agustus 2013. 
Badan Pembinaan Hukum Nasional (BPHN) Departemen Kehakiman dan Hak Asasi Manusia RI, "Laporan Hasil Seminar Pembangunan Hukum Nasional VIII"KutaBali, 14-18 Juli 2003.

Marcus Priyo Gunarto, "Asas Keseimbangan dalam Konsep Rancangan UndangUndang Kitab Undang-Undang Hukum Pidana", Jurnal Mimbar Hukum, Vol. 24, Nomor 1, Februari 2012.

Muladi, "Politik Hukum Pidana, Dasar Kriminalisasi dan Dekriminalisasi serta Beberapa Perkembangan Asas dalam RUU KUHP", makalah yang dipresentasikan dalam Focus Group Discussion yang diselenggarakan oleh ELSAM dengan tema: Melihat Kodifikasi dalam Rancangan KUHP, Jakarta, 28 September 2006.

Solly Lubis, "Pembangunan Hukum Nasional”, makalah disampaikan dalam Seminar Pembangunan Hukum Nasional VII, dengan tema: Penegakan Hukum Dalam Era Pembangunan Berkelanjutan yang diselenggarakan oleh Badan Pembinaan Hukum Nasional, Departemen Kehakiman dan Hak Asasi Manusia, DenpasarBali, 14-18 Juli 2003.

Valerine J.L. Kriekhoff, "Arah Pembaharuan Hukum Pidana Nasional - Penggunaan Hukum Adat", Makalah dipresentasikan pada Seminar Pengkajian Hukum Nasional Tahun 2013 (SPHN 2013) dengan tema "Arah Pembangunan Hukum Pidana Nasional" yang diselenggarakan oleh Komisi Hukum Nasional (KHN), Jakarta, 26-27 November 2013.

Varia Peradilan No. 122 Tahun 1999.

Yong Ohoitimur, "Tujuh Teori Etika Tentang Tujuan Hukum", Jurnal Universitas De La Salle, Vol. 1, No. 2, Oktober 2011.

\section{Dokumen Hukum}

Undang-Undang Dasar Negara Republik Indonesia 1945. 